\title{
PENGARUH PROMOTION MIX TERHADAP CUSTOMER LOYALTY MELALUI BRAND EQUITY SEBAGAI VARIABEL MEDIASI
}

\section{Nyoman Putri Widyasari ${ }^{1}$ I Gde Ketut Warmika ${ }^{2}$}

\author{
${ }^{1,2}$ Fakultas Ekonomi dan Bisnis Universitas Udayana (Unud), Bali, Indonesia \\ email: putriwidyaa25@gmail.com
}

\begin{abstract}
ABSTRAK
Penelitian ini menjelaskan peran brand equity memediasi pengaruh promotion mix terhadap customer loyalty. Penelitian ini dilakukan di kota Denpasar yang melibatkan 100 responden. Penelitian menggunakan kuesioner, observasi dan wawancara. Digunakan analisis jalur dan uji sobel. Hasil penelitian adalah Promotion mix berpengaruh positif dan signifikan terhadap brand equity, Promotion mix berpengaruh positif dan signifikan terhadap customer loyalty, Brand equity berpengaruh positif signifikan terhadap customer loyalty, dan Brand equity memediasi pengaruh promotion mix terhadap customer loyalty. Pihak manajemen Acer untuk lebih memperhatikan promosi penjualan dan penjualan perorangan pada promotion mix. Meningkatkan promosi penjualan dengan cara memberikan potongan harga, presentasi hadiah berulang seperti geratis aksesoris laptop pada tipe tertentu, menyebarkan catalog promosi, serta meningkatkan penjualan perorangan dengan cara berkonsentrasi pada pelatihan tenaga penjualan di berbagai bidang.
\end{abstract}

Kata kunci: promotion mix, customer loyalty, brand equity.

\begin{abstract}
This study explains the role of brand equity mediates the effect of promotion mix on customer loyalty. This research was conducted in the city of Denpasar involving 100 respondents. The study used questionnaires, observation and interviews. Path analysis and sobel test were used. The results of the study are that Promotion mix has a positive and significant effect on brand equity, Promotion mix has a positive and significant effect on customer loyalty, Brand equity has a significant positive effect on customer loyalty, and Brand equity mediates the effect of promotion mix on customer loyalty. Acer management to pay more attention to individual sales and sales promotions on promotion mix. Increase sales promotion by giving discounts, presenting repeat prizes such as geratis laptop accessories in certain types, distributing promotional catalogs, and increasing individual sales by concentrating on training salespeople in various fields.

Keywords: promotion mix, customer loyalty, brand equity.
\end{abstract}




\section{PENDAHULUAN}

Perkembangan teknologi di era sekarang ini sangat canggih dan pesat. Hal ini dapat dibuktikan dengan banyaknya inovasi yang diterima secara global. Salah satunya adalah komputer. Menurut Williams dan Sawyer (2011:4) komputer adalah mesin multiguna yang dapat diprogram, yang menerima data (fakta-fakta dan gambar-gambar kasar) dan memproses atau memanipulasinya ke dalam informasi yang dapat kita gunakan.

Semakin berkembangnya teknologi, komputer mulai di revolusi menjadi perangkat yang lebih kecil sehingga lebih praktis untuk dibawa kemana-mana yang dinamakan laptop. Pengguna laptop dalam bekerja sangat membantu dan memudahkan penyelesaian pekerjaannya. Inilah salah satu manfaat laptop di Indonesia yang dinilai cukup positif. Salah satu dari banyaknya produsen laptop yang menjual produknya di Indonesia sampai saat ini adalah Acer.

Dikutip dari Acer Inc Wikipedia Indonesia (2017) menyatakan bahwa laptop Acer ini merupakan salah satu lini produk dari Grup Pan Acer. Acer didirikan pada 1976 oleh Stan Shin et al. di Taipei Taiwan. Menurut IDC PC Tracker and Garner INC pada laman acerid.com (2017), Acer Indonesia mulai beroperasi tahun 1998 dan saat ini telah menjadi pemain utama di industri PC Indonesia. Acer mencatat pertumbuhan yang stabil dan positif di pasar Indonesia, terbukti dengan berhasil menjadi merek No.1 untuk kategori laptop selama 8 tahun berturut-turut dan No.1 untuk kategori PC selama 7 tahun berturut-turut di Indonesia. Acer Indonesia telah meraih berbagai penghargaan bergengsi dari berbagai institusi, di antaranya Top Brand Award, Indonesia Best Brand Award dan Indonesia Customer Satisfaction Award. Acer berkomitmen untuk menjalin komunikasi tanpa batas dengan konsumen di seluruh Indonesia.

Menurut Acer Indonesia (2018), tahun 2018 Acer kembali membuktikan sebagai laptop pilihan masyarakat Indonesia dengan memenangkan Top Brand Award 2018 yang diselenggarakan oleh majalah Marketing and Frontier Consulting Group, dalam kategori yakni kategori Notebook/Laptop. Untuk kategori Notebook/Laptop, penghargaan tahun ini merupakan yang kesebelas kalinya, yang secara berturut-turut diraih oleh Acer Indonesia sejak tahun 2008.

Tingkat persaingan berbagai macam merek laptop yang dipasarkan di Indonesia dapat diketahui pada data hasil survei yang diberikan oleh TOP Brand Award (2018), Top Brand Index dari sektor telekomunikasi yang dilakukan pada 14.000 responden di 15 kota besar di Indonesia, yaitu Jabodetabek, Bandung, Semarang, Yogyakarta, Surabaya, Malang, Medan, Pekanbaru, Palembang, Balikpapan, Samarinda, Banjarmasin, Makassar, Denpasar, dan Manado. Data TBI mampu memberikan ukuran kesuksesan sebuah merek di pasar melalui tiga parameter atau pengukuran dimensi yaitu Mindshare (Top of Mind) yang berarti mengindikasikan kekuatan merek di benak konsumen, Market Share (Last Usage) yaitu menunjukkan kekuatan merek di pasar dalam hal perilaku pembelian aktual konsumen yang terakhir Commitment Share (Future Intention) yaitu mengindikasikan tersebut di masa yang akan datang. Menurut Herbet Ang, Presiden Direktur Acer Indonesia dalam acerid.com (2018) mengatakan penghargaan yang didapat menunjukkan kemampuan Acer Indonesia dalam 
mempertahankan kesetiaan atau loyalitas dan kepuasan pelanggan terhadap brand, tidak saja bagi pelanggan tapi juga korporasi dan enterprise.

Tabel 1. menunjukan data TBI (Top Brand Index) kategori telekomunikasi atau laptop, notebook, dan netbook tahun 2016, 2017, dan 2018 pada fase 1.

Tabel 1.

Top Brand Index Kategori Telekomunikasi / IT Laptop, Notebook, dan Netbook

\begin{tabular}{cccc}
\hline Merek & TBI 2016 & TBI 2017 & TBI \\
\hline Acer & $34.7 \%$ & $33.7 \%$ & $31.7 \%$ \\
Toshiba & $10.8 \%$ & $10.9 \%$ & $7.1 \%$ \\
Asus & $16.5 \%$ & $18.1 \%$ & $23.6 \%$ \\
Hp & $8.5 \%$ & $8.9 \%$ & $9.4 \%$ \\
Lenovo & $11.1 \%$ & $10.5 \%$ & $10.9 \%$ \\
Apple & $3.3 \%$ & $3.1 \%$ & - \\
Samsung & $4.6 \%$ & $4.8 \%$ & - \\
\hline
\end{tabular}

Sumber: Top Brand Award, Maret 2018

Tabel 1. menunjukkan bahwa presentase merek Acer tertinggi pada tahun 2016 yaitu sebesar 34,7 persen, pada tahun 2017 menurun menjadi 33,7 persen dan terakhir juga menurun pada tahun 2018 sebanyak 2 persen menjadi 31,7 persen. Walaupun persentase di tiap tahunnya menurun, produk Acer masih tetap jauh unggul di atas dari pada pesaing-pesaingnya. Keunggulan ini dapat dilihat dari perbedaan peringkat Acer dengan kompetitornya yaitu Asus dan Lenovo pada tahun 2018 ini cukup jauh, yaitu Asus dengan perolehan 23,6 persen dan Lenovo 10,9 persen.

Data yang semakin menurun tersebut mengharuskan Acer untuk meningkatkan keunggulan bersaing dengan tetap mempertahankan loyalitas pelanggannya. Untuk mengetahui faktor yang mempengaruhi berpindahnya pelanggan yang menggunakan Acer ke pesaingnya maka dilakukan pra survei. Pra survei ini dilakukan oleh 20 responen yang telah menjadi pelanggan Acer. Beberapa pernyataan terkait indikator dari promotion mix, brand equity, dan customer loyalty untuk mengetahui bagaimana hasil survei sementara ini. Berikut adalah beberapa pernyataan yang ditujukan untuk responden.

Pernyataan pra survei dibawah ditanyakan pada 20 responden dengan memilih setuju atau tidak setuju dengan pernyataan yang diberikan. Hasil pra survei pada Tabel 2. diketahui bahwa promotion mix dengan indikator promosi penjualan sebanyak 12 responden yang menjawab setuju dan sebanyak 8 responden menjawab tidak setuju. Perusahaan laptop merek Acer kurang meningkatkan promosi penjualan dan periklanan pada produknya sehingga kekuatan merek di pasaran menjadi menurun. Hal ini menjadikan peningkatan nilai merek bagi pesaing Acer seperti Asus. Selanjutnya brand equity dengan indikator kesadaran merek sebanyak 16 responden yang menjawab setuju dan sebanyak 4 responden menjawab tidak setuju. Walaupun hasil ini terbesar, jika 
tidak diimbangi dengan promosi yang baik, maka nilai kekuatan merek bisa menurun. Sedangkan customer loyalty dengan indikator kepuasan sebanyak 15 responden menjawab setuju dan 5 responden menjawab tidak setuju.

Tabel 2.

Tabel Pernyataan dan Hasil Pra Survei

\begin{tabular}{|c|c|c|c|c|}
\hline \multirow[b]{2}{*}{ Variabel } & \multirow[b]{2}{*}{ Indikator } & \multirow[b]{2}{*}{ Pernyataan } & \multicolumn{2}{|c|}{ Jumlah Responden } \\
\hline & & & $\begin{array}{c}\text { Setuju } \\
\text { Setuju }\end{array}$ & Tidak \\
\hline $\begin{array}{l}\text { Promotion } \\
\text { Mix }\end{array}$ & $\begin{array}{l}\text { Promosi } \\
\text { Penjualan }\end{array}$ & $\begin{array}{l}\text { Saya tertarik dengan } \\
\text { promosi penjualan dari } \\
\text { produk laptop merek } \\
\text { Acer }\end{array}$ & 12 & 8 \\
\hline $\begin{array}{l}\text { Brand } \\
\text { Equity }\end{array}$ & $\begin{array}{l}\text { Kesadaran } \\
\text { Merek }\end{array}$ & $\begin{array}{l}\text { Saat memikirkan } \\
\text { tentang laptop, merek } \\
\text { Acer selalu muncul } \\
\text { dalam pikiran saya }\end{array}$ & 16 & 4 \\
\hline $\begin{array}{l}\text { Customer } \\
\text { Loyalty }\end{array}$ & Kepuasan & $\begin{array}{l}\text { Saya tetap } \\
\text { menggunakan laptop } \\
\text { merek Acer sekalipun } \\
\text { tersedia banyak merek } \\
\text { laptop lainnya. }\end{array}$ & 15 & 5 \\
\hline
\end{tabular}

Acer perlu meningkatkan promosi penjualan produknya untuk meningkatkan kembali kesetiaan pelanggan terhadap laptop Acer. Melihat hasil pra survei tersebut dan adanya keunggulan menjadi peringkat tertinggi dalam TBI, Acer diharapkan mampu memanfaatkan kekuatan brand equity dengan meningkatkan promotion mix untuk menjaga pertumbuhan penjualan. Sehingga faktor promosi dan bagaimana merek yang tertanam dalam pikiran konsumen sangatlah penting terhadap loyalitas pelanggan dalam membeli sebuah produk.

Promotion mix adalah salah satu bagian dari marketing mix. Promotion mix adalah cara-cara untuk berbagai jenis promosi sehingga dapat meningkatkan penjualan dan pemasaran produk pada suatu perusahaan. Promosi merupakan kegiatan yang ditujukan untuk mempengaruhi konsumen agar mereka dapat mengenali akan produk yang ditawarkan oleh perusahaan sehingga timbulah loyalitas konsumen pada produk tersebut.

Menurut Kotler \& Keller (2009:138) loyalitas adalah sebuah komitmen yang dimiliki pelanggan untuk melakukan pembelian kembali barang atau jasa di masa mendatang meski pengaruh situasi dan usaha pemasaran yang nanti menyebabkan pelanggan beralih. Nuraini (2009) menyatakan bahwa pelanggan yang setia adalah mereka yang sangat puas dengan produk tertentu sehingga mempunyai antusiasme untuk memperkenalkannya kepada siapapun yang mereka kenal.

Loyalitas pelanggan merupakan sikap menyenangi terhadap suatu merek yang direpresentasikan dalam pembelian yang konsisten terhadap merek sepanjang waktu dengan nilai yang dirasakan pada suatu produk Shahroudi \& Naimi (2015). Loyalitas pelanggan memiliki peran penting dalam sebuah perusahaan mempertahankan pelanggan berarti meningkatkan kinerja keuangan dan mempertahankan kelangsungan hidup perusahaan. Hal ini menjadi alasan 
utama bagi sebuah perusahaan untuk menarik dan mempertahankan pelanggan maka perlu dilakukan pengendalian terhadap promosi produk. Khanfar (2016) menyatakan untuk menciptakan penjualan dan keuntungan, keunggulan dari produk perlu di komunikasikan kepada konsumen melalui bauran promosi. Pengaruh bauran promosi terhadap loyalitas pelanggan menurut Permatasari (2014), Faries dan Budiyanto (2017) dan Sembeng (2016) dalam penelitiannya bauran promosi berpengaruh secara positif dan signifikan terhadap loyalitas konsumen.

Namun menurut penelitian yang dilakukan Diansyah dan Putera (2017) mendapatkan hasil bahwa promosi tidak mempunyai pengaruh terhadap loyalitas pelanggan. Hal ini dikarenakan kurang menariknya promosi yang dilakukan oleh Telkomsel yang menyebabkan loyalitas pelanggan semakin berkurang. Berdasarkan penelitian tersebut, maka penelitian ini menggunakan variabel brand equity sebagai mediasi guna mendapatkan hasil yang positif dan signifikan antara pengaruh promotion mix terhadap customer loyalty.

Pourdehghan (2015) salah satu faktor penting dan utama dalam menjaga pelanggan dan meningkatkan penjualan adalah melalui bauran pemasaran. Dimensi dari bauran pemasaran yaitu promosi dan produk dapat meningkatkan kekuatan ekuitas merek, kepuasan dan loyalitas pelanggan. Menurut $\mathrm{Hu}$ (2012) ekuitas merek memediasi hubungan antara bauran promosi, kualitas layanan dan loyalitas pelanggan. Ini berarti ekuitas merek memainkan peran penting untuk mempengaruhi persepsi pelanggan pada promosi, kualitas layanan dan loyalitas pelanggan.

Promosi pada dasarnya adalah cara produsen untuk bisa berkomunikasi dengan produk tersebut ataupun menyadari akan keberadaan produk tersebut. Abdurrahman (2015:156) mengartikan bauran promosi sebagaimana bauran komunikasi pemasaran adalah paduan spesifik periklanan, promosi penjualan, hubungan masyarakat, penjualan personal, dan pemasaran langsung yang digunakan perusahaan untuk mengkomunikasikan nilai pelanggan secara persuasif dan membangun hubungan pelanggan. Kotler dan Keller (2009:174) mengatakan komunikasi pemasaran mempunyai andil dalam brand equity bagi perusahaan. Velnampy dan Sivanandamoorthy (2012) menyatakan bahwa pemasaran yang termasuk didalamnya adalah promosi berhubungan positif dengan ekuitas merek.

Charanah dan Njuguna (2015) menyatakan untuk memberikan bentuk untuk ekuitas merek selalu diperlukan kegiatan promosi yang membantu menciptakan nilai merek sehingga pelanggan dapat melakukan pembelian ulang dimasa mendatang. Menurut Hu (2011) serta Kumar dan Patra (2017) bauran promosi dan ekuitas merek mempunyai pengaruh langsung. Dewantara dan Nurcahya (2017) pun menyebutkan hal yang sama dimana variabel bauran promosi memiliki pengaruh positif dan signifikan terhadap ekuitas merek. Pengaruh positif artinya ketika strategi promosi yang dilakukan optimal maka kekuatan ekuitas merek dari produk tersebut akan meningkat.

Menurut Chriswardana (2015) semakin kuat ekuitas merek suatu produk, semakin kuat pula niat konsumen untuk mengkonsumsi produk tersebut. Bagi pelanggan ekuitas merek dapat memberikan nilai dalam memperkuat pemahaman mereka akan proses informasi memupuk rasa percaya diri dalam pembelian serta 
meningkatkan pencapaian kepuasan. Sumarwan et al. (2009) mengartikan brand equity sebagai daya tarik pelanggan. Ketatnya persaingan antar produk meningkatkan tendensi konsumen untuk beralih ke produk lain, lebihnya lagi terhadap produk yang memiliki ketidaksesuaian antara nilai yang diberikan dengan ekspektasi konsumen menurut Anindhyta et al. (2013). Ekuitas merek adalah nilai yang ditentukan oleh konsumen pada suatu merek di atas dan di luar karakteristik/atribut fungsional dari produk demi menciptakan loyalitas pelanggan terhadap sebuah merek menurut Supranto dan Limakrisna (2011:132). Nilai yang dirasakan pelanggan ini merupakan salah satu penentu yang paling penting dari pembelian sehingga seseorang bersedia untuk membeli (Chang dan Wang, 2011). Ekuitas merek dapat membuat produk lebih berbeda dengan merek lainnya, lebih dikenal konsumen dan lebih mendapat respon yang baik dari konsumen (Norouzi dan Hosienabadi, 2011).

Tujuan yang ingin dicapai dari penelitian ini adalah menjelaskan pengaruh promotion mix terhadap brand equity, menjelaskan pengaruh promotion mix terhadap customer loyalty, menjelaskan pengaruh brand equity terhadap customer loyalty, dan menjelaskan pengaruh promotion mix terhadap customer loyalty melalui brand equity sebagai variabel mediasi khususnya pada pengguna laptop merek Acer di kota Denpasar. Hasil penelitian ini diharapkan dapat memberikan manfaat untuk menambah referensi yang digunakan sebagai bahan masukan bagi peneliti yang lain ingin melakukan penelitian dalam ruang lingkup yang sama yaitu mengenai pengaruh promotion mix terhadap customer loyalty melalui brand equity sebagai variabel mediasi. Kemudian dapat dijadikan sebagai bahan pertimbangan bagi manajemen perusahaan Acer dalam menetapkan kebijakan strategi dalam penggunaan promotion mix dan brand equity terhadap customer loyalty agar tetap setia pada produk Acer.

Kotler bersama dengan Keller dan Burton menyatakan bahwa ada keterhubungan antara promotion mix dengan brand equity (Kotler \& Keller, 2009:511). Teori Kotler dan Keller tersebut menjelaskan bahwasannya bauran promosi yang memiliki lima elemen, yaitu advertising, sales promotion, public relation, personal selling, dan direct marketing, dikatakan memiliki keterhubungan dengan ekuitas merek.

Menurut penelitian Hosseini dan Moezzi (2015), Rohollah et al. (2014), Danibrata (2011), Brunello (2013) serta Shafi dan Madhavaiah (2013) mendapatkan hasil bahwa promotion mix memberikan pengaruh positif signifikan terhadap brand equity. Berdasarkan kajian empiris dari hasil penelitian sebelumnya, dapat di bangun hipotesis sebagai berikut:

$\mathrm{H}_{1}$ : Promotion mix berpengaruh positif dan signifikan terhadap brand equity pada pengguna laptop merek Acer.

Menurut Peter dan Olson (1999:2015) promotion mix memperkuat customer loyalty akan suatu produk yang ditawarkan, hal ini dikarenakan sebagian konsumen cenderung membeli suatu produk atau jasa didasarkan pada kupon dan tawaran-tawaran lainnya, maka pemberian tawaran yang menarik secara rutin akan membuat mereka relatif loyal pada suatu merek yang dipromosikan.

Yeni (2016) dalam penelitiannya bauran promosi berpengaruh secara positif dan signifikan terhadap loyalitas konsumen. Menurut Ghaisani dkk. (2016) 
promotion mix yang paling dominan berpengaruh terhadap customer loyalty adalah sales promotion dan word of mouth. Sedangkan Sukmarini dkk. (2013) menunjukkan bahwa secara parsial variabel strategi bauran promosi memberikan pengaruh yang positif dan signifikan terhadap loyalitas pelanggan. Berdasarkan kajian empiris dari hasil penelitian sebelumnya, dapat di bangun hipotesis sebagai berikut:

$\mathrm{H}_{2}$ : Promotion mix berpengaruh positif dan signifikan terhadap customer loyalty pada pengguna laptop merek Acer.

Sumarwan et al. (2009:326) mengemukakan bahwa loyalitas adalah sikap positif seorang konsumen atau pelanggan terhadap suatu merek, konsumen memiliki keinginan kuat untuk membeli ulang merek yang sama pada saat sekarang maupun masa datang. Istijanto, 2005:172) mengemukakan loyalitas atau kesetiaan pelanggan merupakan probabilitas seorang konsumen untuk membeli atau memakai produk atau merek secara berulang dalam periode waktu tertentu.

Hasil pengujian yang dilakukan Maharani (2010), Darmawangsa dan Ardani (2015) serta Diansyah dan Putera (2017) terdapat hubungan yang positif dan signifikan antara ekuitas merek dengan loyalitas konsumen. Penelitian ini juga serupa dengan hasil yang dinyatakan oleh Alghofari dkk. (2009) serta Alyasa dan Kuntilawati (2012) yang menunjukkan peran ekuitas merek sebagai komponen fundamental dalam strategi pemasaran untuk membangun korelasi sejati dengan konsumen. Berdasarkan kajian empiris dari hasil penelitian sebelumnya, dapat di bangun hipotesis sebagai berikut:

$\mathrm{H}_{3}$ : Brand equity berpengaruh positif dan signifikan terhadap customer loyalty pada pengguna laptop merek Acer.

Danibrata (2011) menyatakan promosi hanya berlangsung untuk jangka pendek, namun ekuitas merek penting untuk dikelola dengan baik oleh perusahaan, karena kumpulan aset serta liabilitas merek agar konsumen tetap loyal dengan suatu produk dan mencegah tergerusnya produk dari ketatnya persaingan pasar dan menjadi senjata bagi perusahaan mengatasi konsumen berpindah menggunakan produk lain.

Menurut $\mathrm{Hu}$ (2011) dalam penelitian yang dilakukan menunjukkan ekuitas merek, kualitas layanan, dan strategi bauran pemasaran termasuk didalamnya bauran promosi memiliki hubungan yang signifikan dan positif dengan loyalitas pelanggan. Hu juga melalukan penelitian selanjutnya di tahun 2012 dengan hasil ekuitas merek memediasi hubungan antara bauran promosi, kualitas layanan dan loyalitas pelanggan. Ini berarti ekuitas merek memainkan peran penting untuk mempengaruhi persepsi pelanggan pada promosi, kualitas layanan dan loyalitas pelanggan. Selain itu, hasil analisis jalur menunjukkan strategi bauran pemasaran adalah bauran promosi secara parsial memediasi hubungan antara kualitas layanan dan loyalitas pelanggan ( $\mathrm{Hu}, 2012)$. Berdasarkan kajian empiris dari hasil penelitian sebelumnya, dapat di bangun hipotesis sebagai berikut:

$\mathrm{H}_{4}$ : Brand equity berperan dalam memediasi pengaruh variabel promotion mix terhadap customer loyalty pada pengguna laptop merek Acer. 


\section{METODE PENELITIAN}

Penelitian ini menggunakan pendekatan kuantitatif yg berbentuk asosiatif. Lokasi penelitian ini dilakukan di kota Denpasar. Obyek dalam penelitian ini adalah mengenai loyalitas pelanggan dalam pembelian laptop merek Acer yang ditentukan oleh promotion mix dan brand equity. Variabel eksogen dalam penelitian ini adalah promotion mix $(\mathrm{X})$. Variabel mediasi dalam penelitian ini adalah ini adalah brand equity $(\mathrm{M})$. Variabel endogen dalam penelitian ini adalah customer loyalty (Y). Data kualitatif dalam penelitian ini adalah jenis kelamin responden, pendidikan terakhir responden, dan pekerjaan responden. Data kuantitatif dalam penelitian ini berupa data pra survei dan data brand laptop di Indonesia mulai tahun 2016 sampai 2018 kemudian bersumber dari TBI, hasil penelitian responden kepada pernyataan kuisioner. Data primer pada penelitian ini ialah responden yang memberikan penilaian atas pernyataan yang ada pada kuisioner mengenai variabel-variabel pada penelitian. Data sekunder pada penelitian ini ialah institusi serta pihak terkait yang mempublikasikan data yang dikutip berkaitan pada topik penelitian, seperti top brand award. Populasi dalam penelitian ini adalah masyarakat Kota Denpasar yang telah membeli dan menggunakan produk laptop merek Acer lebih dari satu kali hingga saat ini. Sampel dari penelitian ini adalah 100 responden. Metode pengumpulan data dalam penelitian ini adalah metode non-probabilitysampling yaitu teknik pengambilan sampel yang tidak memberi peluang atau kesempatan yang sama bagi setiap unsur atau anggota populasi untuk dipilih menjadi sampel. Data dikumpulkan menggunakan instrumen penelitian berupa kuesioner.

Uji Validitas dilakukan untuk mengukur sah atau valid tidaknya suatu kuisioner. Suatu item dikatakan valid jika pernyataan pada kuisioner mampu untuk mengungkapkan sesuatu yang akan diukur oleh kuisioner tersebut. Untuk mengukur validitas instrumen dalam penelitian ini digunakan korelasi Pearson Correlation dengan bantuan statistical package for social science (SPSS) for windows. Suatu instrumen dikatakan valid jika nilai $\mathrm{r}$ Pearson Correlation terhadap skor total diatas 0,3, (Ghozali, 2013:52). Uji reliabilitas dimaksudkan untuk mengukur seberapa besar suatu pengukuran mengukur dengan stabil atau konsisten. Instrumen dipercaya jika jawaban dari responden atas pernyataan adalah konsisten atau stabil dari waktu ke waktu. Uji ini dilakukan dengan menggunakan koefisien crobach alpha dengan bantuan program SPSS. Uji reliabilitas dilakukan terhadap instrumen dengan koefisien crobach alpha $>0,60$ maka instrumen yang digunakan reliabel. Uji reliabilitas akan diukur dengan menggunakan program komputer Statistic Package of Social Science for windows, (Ghozali, 2013:42).

Analisis statistik deskriptif adalah statistik yang digunakan untuk menganalisis data dengan cara mendeskripsikan atau menggambarkan data yang berkaitan dengan karakteristik variabel penelitian yaitu nilai rata-rata, standar deviasi, varian, nilai minimum, tabel frekuensi, karakteristik responden, rata-rata hitung, dan nilai maksimum yang telah terkumpul sebagaimana adanya tanpa bermaksud membuat kesimpulan yang berlaku untuk umum atau generalisasi, menurut Sugiyono (2014:207). 
Statistik inferensial adalah teknik statistik yang digunakan untuk menganalisis data sampel dan hasilnya diberlakukan untuk populasi. Suatu kesimpulan dari data sampel yang akan diberlakukan untuk populasi itu mempunyai peluang kesalahan dan kebenaran (kepercayaan) yang dinyatakan dalam bentuk presentase. Peluang kesalahan dan kepercayaan ini disebut dengan taraf signifikansi menurut Sugiyono (2014:210). Model regresi dikatakan model yang baik apabila model tersebut bebas dari asumsi klasik statistik. Suatu model secara teoritis akan menghasilkan nilai parameter penduga yang tepat bila memenuhi persyaratan asumsi klasik regresi, yaitu meliputi uji normailitas, multikolineritas, dan heteroskedastisitas. Uji normalitas bertujuan untuk menguji apakah dalam model regresi terdapat variabel pengganggu atau residual memiliki distribusi normal (Ghozali, 2013:160). Seperti diketahui bahwa uji t dan F mengasumsikan bahwa nilai residual mengikuti distribusi normal. Apabila asumsi ini dilanggar maka uji statistik menjadi tidak valid untuk jumlah sampel kecil. Hal ini berarti bahwa perbedaan antara nilai prediksi dengan nilai sebenarnya (error) akan terdistribusi secara simetris di sekitar nilai rata-rata satu sama denggan nol. Salah satu cara mendeteksi normalitas pada penelitian ini dilaksanakan dengan menguji normalitas residual dengan memakai uji statistic Kolmogorov-Smirnov. Data disebutkan berdistribusi dengan normal jikalau koefisien Asymp.Sig diatas dari $\alpha=0,05$. Uji multikolinieritas bertujuan guna menguji apakah pada model regresi ditemukan adanya korelasi antar variabel bebas (independen) Ghozali (2013:105). Untuk dapat mendeteksi ada atau tidaknya multikolinieritas dapat dilihat dari nilai tolerance dan nilai Variance Inflation Factor (VIF). Jika nilai tolerance $>0,10$ atau Variance Inflation Factor (VIF) $<10$ kemudian disebutkan tidak terdapat multikolinieritas. Multikolinieritas ditandai oleh $\mathrm{R}^{2}$ yg sangat besar namun tidak satupun variabel bebas yg signifikan jika diuji parsial (t) (Utama, 2016:106). Uji heterokedastisitas bertujuan guna menguji apakah pada model regresi terjadi ketidaksamaan varian dari residual satu pengamatan ke pengamatan lainnya (Ghozali, 2013:139). Jikalau varian dari residual satu pengamatan ke pengamatan lainnya tetap, kemudian dikatakan homoskedastisitas serta apabila terdapat berbeda dikatakan dengan heteroskedastisitas. Model regresi yg baik ialah model regresi yg memiliki varian yg homogen. Kemudian suatu model regresi mengandung gejala heteroskedasitas lalu akan memberikan hasil yg menyimpang.

Analisis jalur adalah suatu bentuk terapan dari analisis multi regresi, analisis jalur digunakan untuk menguji kemungkinan dari suatu hubungan sebab akibat diantara tiga variabel atau lebih. Langkah-langkah dalam menganalisis data menggunakan path analysis adalah sebagai berikut: 1). Merumuskan hipotesis dan persamaan structural, 2). Bentuk diagram koefisien jalur, 3). Menghitung koefisien jalur secara simultan, 4). Menghitung koefisien jalur secara individual, 5). Meringkas dan menyimpulkan.

Uji Sobel digunakan dengan menguji kekuatan pengaruh tidak langsung variabel promotion mix (X) pada variabel customer loyalty $(\mathrm{Y})$ melalui variabel brand equity $(\mathrm{M})$. (M) dihitung menggunakan cara mengalikan koefisien jalur $\mathrm{X}$ pada M (a) dengan koefisien jalur M pada Y (b) atau ab. Standar error koefisien a 
serta $\mathrm{b}$ ditulis dengan $\mathrm{Sa}$ dan $\mathrm{Sb}$, besarnya standar error tidak langsung (indirect effect).

\section{HASIL DAN PEMBAHASAN}

Tabel 3.

Karakteristik Responden

\begin{tabular}{|c|c|c|c|c|}
\hline No. & Variabel & Klasifikasi & $\begin{array}{l}\text { Jumlah } \\
\text { (orang) }\end{array}$ & $\begin{array}{c}\text { Presentase } \\
(\%)\end{array}$ \\
\hline \multirow{4}{*}{1} & \multirow{4}{*}{ Umur } & 17-22 tahun & 79 & 79 \\
\hline & & $23-28$ tahun & 11 & 11 \\
\hline & & 29-34 tahun & 4 & 4 \\
\hline & & $<35$ tahun & 6 & 6 \\
\hline \multirow{4}{*}{2} & Jumlah & & 100 & 100 \\
\hline & \multirow{3}{*}{$\begin{array}{c}\text { Jenis Kelamin } \\
\text { Jumlah }\end{array}$} & Laki-laki & 30 & 30 \\
\hline & & Perempuan & 70 & 70 \\
\hline & & & 100 & 100 \\
\hline \multirow{5}{*}{3} & \multirow{5}{*}{ Pendidikan Terakhir } & SMA/ SMK/ Sederajat & 84 & 84 \\
\hline & & Diploma & 2 & 2 \\
\hline & & Strata 1 & 13 & 13 \\
\hline & & Strata 2 & 1 & 1 \\
\hline & & Strata 3 & 0 & 0 \\
\hline & Jumlah & & 100 & 100 \\
\hline \multirow{6}{*}{4} & \multirow{5}{*}{ Pekerjaan } & Pelajar/ Mahasiswa & 70 & 70 \\
\hline & & PNS/ ABRI & 8 & 8 \\
\hline & & Pegawai Swasta & 15 & 15 \\
\hline & & Wiraswasta & 6 & 6 \\
\hline & & Ibu Rumah Tangga & 1 & 1 \\
\hline & Jumlah & & 100 & 100 \\
\hline
\end{tabular}

Sumber: Data diolah, 2018

Karakteristik responden dapat dilihat berdasarkan pengelompokan umur, umur kisaran 17 tahun sampai 22 tahun mendominasi dalam penelitian ini melalui presentase senilai 79 persen, ini disebabkan pada rentang usia itu responden lebih memilih membeli dan menggunakan laptop merek Acer. Selanjutnya, diikuti oleh responden berusia 23 tahun sampai dengan 28 tahun dan 29 tahun sampai dengan 34 tahun melalui jumlah persentase masing-masing senilai 11 persen dan 4 persen pada peringkat kedua dan ketiga. Peringkat terakhir yaitu responden usia lebih dari 35 tahun dengan persentase senilai 5 persen. Jumlah reponden didominasi berjenis kelamin perempuan ialah sebanyak 70 responden, dan sisanya terdiri dari 30 responden laki-laki. Sedangkan responden pada tingkat pendidikan terakhir yang mendominasi adalah SMA atau SMK atau Sederajat dengan persentase 84 persen, Diploma 2 persen, Strata 1 ada 13 persen, dan terakhir Strata 2 hanya 1 persen. Tidak ada responden dengan pendidikan terakhir Strata 3.

Selanjutnya dlihat dari pekerjaan responden didominasi oleh pelajar atau mahasiswa dengan persentase 70 persen, diurutan kedua responden yang berprofesi sebagai pegawai swasta sebesar 15 persen. Sebanyak 8 persen dengan profesi PNS atau ABRI, sedangankan wiraswasta hanya 6 persen, serta diikuti responden sebagai Ibu rumah tangga berada pada urutan terakhir dengan presentase 1 persen. Hal ini mengindikasikan bahwa responden dengan rentang 
umur 17 tahun sampai 22 tahun yang juga berprofesi sebagai pelajar atau mahasiswa dan pegawai swasta banyak yang menggunakan laptop merek Acer dan konsumen cenderung mencari produk yang dapat memenuhi kebutuhan dan keinginannya.

Tabel 4.

Hasil Uji Validitas

\begin{tabular}{|c|c|c|c|c|}
\hline No & Variabel & Item Pernyataan & $\begin{array}{c}\text { Korelasi Item } \\
\text { Total }\end{array}$ & Keterangan \\
\hline \multirow{5}{*}{1} & \multirow{5}{*}{$\begin{array}{l}\text { Promotion } \\
\text { Mix (X) }\end{array}$} & Periklanan & 0,763 & Valid \\
\hline & & Promosi Penjualan & 0,730 & Valid \\
\hline & & Hubungan Masyarakat & 0,743 & Valid \\
\hline & & Penjualan Perorangan & 0,827 & Valid \\
\hline & & Pemasaran Langsung & 0,786 & Valid \\
\hline \multirow{4}{*}{2} & \multirow{4}{*}{$\begin{array}{l}\text { Brand Equity } \\
\text { (M) }\end{array}$} & Kesadaran Merek & 0,838 & Valid \\
\hline & & Asosiasi Merek & 0,831 & Valid \\
\hline & & Persepsi Kualitas Merek & 0,741 & Valid \\
\hline & & Loyalitas Merek & 0,605 & Valid \\
\hline \multirow{5}{*}{3} & \multirow{5}{*}{$\begin{array}{c}\text { Customer } \\
\text { Loyalty (Y) }\end{array}$} & Kepuasan & 0,817 & Valid \\
\hline & & Ikatan Emosi & 0,919 & Valid \\
\hline & & Kepercayaan & 0,883 & Valid \\
\hline & & Kemudahan & 0,754 & Valid \\
\hline & & History with the company & 0,815 & Valid \\
\hline
\end{tabular}

Sumber: Data diolah, 2018

Hasil uji validitas pada Tabel 4. Memperlihatkan jika seluruh variabel mempunyai nilai koefisien korelasi dengan skor total kesemua item pernyataan lebih besar dari 0,30. Ini memperlihatkan jika butir-butir pernyataan pada instrumen penelitian tersebut valid.

Tabel 5.

Hasil Uji Reliabilitas

\begin{tabular}{clcc}
\hline No. & Variabel & Cronbach's Alpha & Keterangan \\
\hline 1 & Promotion Mix $(\mathrm{X})$ & 0,828 & Reliabel \\
2 & Brand Equity $(\mathrm{M})$ & 0,747 & Reliabel \\
3 & Customer Loyalty $(\mathrm{Y})$ & 0,885 & Reliabel \\
\hline
\end{tabular}

Sumber: Data diolah, 2018

Suatu instrumen disebutkan reliabel, bila instrumen itu mempunyai nilai Alpha Cronbach lebih dari 0,60. Hasil uji reliabilitas yang disajikan dalam Tabel 5. Memperlihatkan jika setiap variabel mempunyai nilai koefisien Alpha Cronbach lebih dari 0,6. Hal ini bisa dikatakan jika semua variabel dalam penelitian ini ialah reliabel.

Hasil perhitungan pada Tabel 6. Dibawah menunjukkan bahwa nilai responden yang paling tertinggi yaitu 3,09 pada indikator pemasaran langsung dengan pernyataan "Saya mendapatkan respon cepat berbasis pemasaran langsung ketika memiliki pertanyaan tentang produk laptop merek Acer". Sedangkan nilai yang terendah yaitu 2,95 pada indikator promosi penjualan dengan pernyataan "Saya tertarik dengan promosi penjualan dari produk laptop merek Acer". Nilai 
rata-rata keseluruhan persepsi responden mengenai variabel promotion mix adalah sebesar 3,04 dan masuk dalam kriteria tinggi.

Tabel 6.

Deskripsi Penilaian Responden terhadap variabel Promotion Mix

\begin{tabular}{|c|c|c|c|c|c|c|c|}
\hline \multirow[t]{2}{*}{ No } & \multirow[t]{2}{*}{ Pernyataan } & \multicolumn{4}{|c|}{$\begin{array}{c}\text { Jawaban } \\
\%\end{array}$} & \multirow[t]{2}{*}{$\begin{array}{c}\text { Rata- } \\
\text { rata }\end{array}$} & \multirow[t]{2}{*}{ Keterangan } \\
\hline & & STS & TS & $\mathbf{S}$ & SS & & \\
\hline 1 & $\begin{array}{l}\text { Saya dapat dengan mudah } \\
\text { mengetahui informasi produk } \\
\text { laptop merek Acer ini dari iklan } \\
\text { berbagai di media. }\end{array}$ & 2 & 17 & 52 & 29 & 3,08 & Tinggi \\
\hline 2 & $\begin{array}{l}\text { Saya tertarik dengan promosi } \\
\text { penjualan dari produk laptop } \\
\text { merek Acer. }\end{array}$ & 0 & 20 & 65 & 15 & 2,95 & Tinggi \\
\hline 3 & $\begin{array}{l}\text { Menurut saya produk laptop } \\
\text { merek Acer memiliki citra yang } \\
\text { baik melalui kegiatan publisitas } \\
\text { dan humasnya. }\end{array}$ & 0 & 19 & 57 & 24 & 3,05 & Tinggi \\
\hline 4 & $\begin{array}{l}\text { Saya membeli produk laptop } \\
\text { merek Acer karena tertarik } \\
\text { dengan pembahasan produk yang } \\
\text { dilakukan dalam penjualan } \\
\text { perorangan. }\end{array}$ & 2 & 17 & 56 & 25 & 3,04 & Tinggi \\
\hline \multirow[t]{2}{*}{5} & $\begin{array}{l}\text { Saya mendapatkan respon cepat } \\
\text { berbasis pemasaran langsung } \\
\text { ketika memiliki pertanyaan } \\
\text { tentang produk laptop merek } \\
\text { Acer. }\end{array}$ & 0 & 19 & 53 & 28 & 3,09 & Tinggi \\
\hline & Rata-rata variabel pron & tion $n$ & & & & 3,04 & Tinggi \\
\hline
\end{tabular}

Sumber: Data diolah, 2018

Tabel 7.

Deskripsi Penilaian Responden terhadap variabel Brand Equity

\begin{tabular}{|c|c|c|c|c|c|c|c|}
\hline \multirow[t]{2}{*}{ No } & \multirow[t]{2}{*}{ Pernyataan } & \multicolumn{4}{|c|}{$\begin{array}{c}\text { Jawaban } \\
\%\end{array}$} & \multirow[t]{2}{*}{$\begin{array}{l}\text { Rata- } \\
\text { rata }\end{array}$} & \multirow[t]{2}{*}{ Keterangan } \\
\hline & & STS & TS & $\mathbf{S}$ & SS & & \\
\hline 1 & $\begin{array}{l}\text { Laptop merek Acer menjadi } \\
\text { pilihan pertama saya. }\end{array}$ & 5 & 22 & 39 & 34 & 3,02 & Tinggi \\
\hline 2 & $\begin{array}{l}\text { Saat memikirkan tentang } \\
\text { laptop, merek Acer selalu } \\
\text { muncul di dalam pikiran saya. }\end{array}$ & 1 & 21 & 59 & 19 & 2,86 & Tinggi \\
\hline 3 & $\begin{array}{l}\text { Saya merasa laptop merek Acer } \\
\text { memiliki kualitas yang baik. }\end{array}$ & 0 & 12 & 56 & 32 & 3,20 & Tinggi \\
\hline 4 & $\begin{array}{l}\text { Acer memiliki gambaran merek } \\
\text { laptop yang bisa dimiliki oleh } \\
\text { semua golongan. }\end{array}$ & 0 & 6 & 60 & 34 & 3,28 & Tinggi \\
\hline \multicolumn{6}{|c|}{ Rata-rata variabel brand equity } & 3,12 & Tinggi \\
\hline
\end{tabular}


Hasil perhitungan pada Tabel 7. diatas menunjukkan bahwa nilai responden yang paling tertinggi yaitu 3,28 pada indikator loyalitas merek dengan pernyataan "Acer memiliki gambaran merek laptop yang bisa dimiliki oleh semua golongan". Sedangkan nilai yang terendah yaitu 2,86 pada indikator asosiasi merek dengan pernyataan "Saat memikirkan tentang laptop, merek Acer selalu muncul di dalam pikiran saya". Rata-rata kesemua persepsi responden mengenai variabel brand equity ialah sebesar 3,11 serta masuk dalam kriteria tinggi. Hal ini berarti kesemua responden merepresentasikan jika tingkat brand equity atau ekuitas merek oleh Acer tinggi, sehingga sebagian besar responden mengetahui dan memiliki daya ingat terhadap produk laptop merek Acer.

Tabel 8.

Deskripsi Penilaian Responden terhadap variabel Customer Loyalty

\begin{tabular}{|c|c|c|c|c|c|c|c|}
\hline \multirow[t]{2}{*}{ No } & \multirow[t]{2}{*}{ Pernyataan } & \multicolumn{4}{|c|}{$\begin{array}{c}\text { Jawaban } \\
\% \\
\end{array}$} & \multirow[t]{2}{*}{$\begin{array}{c}\text { Rata- } \\
\text { rata }\end{array}$} & \multirow[t]{2}{*}{ Keterangan } \\
\hline & & STS & TS & $\mathbf{S}$ & SS & & \\
\hline 1 & $\begin{array}{l}\text { Saya membeli dan menggunakan } \\
\text { laptop merek Acer lebih dari satu } \\
\text { kali. }\end{array}$ & 1 & 35 & 37 & 27 & 2,90 & Tinggi \\
\hline 2 & $\begin{array}{l}\text { Saya merekomendasikan kepada } \\
\text { keluarga, kerabat, teman-teman } \\
\text { maupun orang lain untuk } \\
\text { membeli laptop merek Acer. }\end{array}$ & 0 & 23 & 59 & 18 & 2,95 & Tinggi \\
\hline 3 & $\begin{array}{l}\text { Saya tetap menggunakan laptop } \\
\text { merek Acer sekalipun tersedia } \\
\text { banyak merek laptop lainnya. }\end{array}$ & 0 & 24 & 50 & 26 & 3,02 & Tinggi \\
\hline 4 & $\begin{array}{l}\text { Saya suka menggunakan laptop } \\
\text { merek Acer. }\end{array}$ & 0 & 8 & 73 & 19 & 3,11 & Tinggi \\
\hline 5 & $\begin{array}{l}\text { Bagi saya laptop merek Acer } \\
\text { adalah yang terbaik. }\end{array}$ & 0 & 23 & 52 & 25 & 3,02 & Tinggi \\
\hline \multicolumn{6}{|c|}{ Rata-rata variabel promotion mix } & $\mathbf{3 , 0 0}$ & Tinggi \\
\hline
\end{tabular}

Sumber: Data diolah, 2018

Hasil perhitungan pada Tabel 8. Memperlihatkan jika nilai rata-rata kesemua persepsi responden tentang variabel customer loyalty ialah sebesar 3,00 serta masuk pada kriteria tinggi. Hal ini berarti secara keseluruhan responden merepresentasikan jika sebagian besar responden loyal terhadap produk laptop merek Acer karena mereka mengetahui tentang promosi yang dilakukan oleh Acer dan juga memiliki ingatan yang baik terhadap laptop merek Acer. Berdasarkan hasil deskripsi persepsi konsumen mengenai loyalitas terhadap laptop merek Acer yang diukut dengan 5 indikator, cenderung menunjukkan nilai rata-rata tertinggi pada pernyataan "Saya suka menggunakan produk laptop merek Acer" dengan nilai sebesar 3,11. Hal ini menunjukkan bahwa secara keseluruhan responden akan tetap loyal terhadap produk laptop merek Acer karena responden suka menggunakan laptop Acer dan didukung dengan promotion mix dan brand equity oleh Acer sehingga responden akan tetap setia pada produk laptop merek Acer. Sedangkan nilai yang terendah yaitu 2,90 pada indikator kepuasan dengan 
pernyataan "Saya membeli dan menggunakan laptop merek Acer lebih dari satu kali”.

Tabel 9.

Hasil Uji Normalitas Struktur 1

\begin{tabular}{cc}
\hline & Unstandardized Residual \\
\hline $\mathrm{N}$ & 100 \\
Kolmogorov-Smirnov & 0,609 \\
Asymp.Sig.(2-tailed) & 0,852 \\
\hline Sumber: Data diolah, 2018
\end{tabular}

Berdasarkan Tabel 9. dapat dilihat bahwa nilai Kolmogorov Smirnov (K-S) sebesar 0,609, sedangkan Asymp. Sig. (2-tailed) sebesar 0,852. Hasil tersebut mengindikasikan bahwa model persamaan regresi tersebut berdistribusi normal karena nilai Asymp. Sig.(2-tailed) lebih besar dari nilai alpha 0,05.

Tabel 10.

Hasil Uji Normalitas Struktur 2

\begin{tabular}{cc}
\hline & Unstandardized Residual \\
\hline $\mathrm{N}$ & 100 \\
Kolmogorov-Smirnov & 0,974 \\
Asymp.Sig.(2-tailed) & 0,299 \\
\hline
\end{tabular}

Sumber: Data diolah, 2018

Berdasarkan Tabel 10. dapat dilihat bahwa nilai Kolmogorov Smirnov (K-S) sebesar 0,974, sedangkan Asymp. Sig. (2-tailed) sebesar 0,299. Hasil tersebut mengindikasikan bahwa model persamaan regresi tersebut berdistribusi normal karena nilai Asymp. Sig.(2-tailed) lebih besar dari nilai alpha 0,05.

Tabel 11.

Hasil Uji Multikolinearitas

\begin{tabular}{ccc}
\hline Variabel & Tolerance & VIF \\
\hline Promotion Mix $(X)$ & 0,769 & 1,300 \\
Brand Equity $(M)$ & 0,769 & 1,300 \\
\hline Sumber: Data diolah 2018 & &
\end{tabular}

Berdasarkan Tabel 11. dapat dilihat bahwa nilai tolerance dan VIF dari variabel promotion mix dan brand equity menunjukan nilai VIF lebih kecil dari 10 yang berarti model persamaan regresi bebas dari multikolinearitas.

Tabel 12.

Hasil Uji Heteroskedastistas Struktur 1

\begin{tabular}{|c|c|c|c|c|c|c|}
\hline & \multirow[t]{2}{*}{ Model } & \multicolumn{2}{|c|}{ Unstandardized Coefficients } & \multirow{2}{*}{$\begin{array}{c}\begin{array}{c}\text { Standardized } \\
\text { Coefficients }\end{array} \\
\text { Beta }\end{array}$} & \multirow[t]{2}{*}{$\mathbf{t}$} & \multirow{2}{*}{ Sig. } \\
\hline & & B & Std. Error & & & \\
\hline \multirow[t]{2}{*}{1} & (Constant) & 0,402 & 0,161 & & 2,490 & 0,014 \\
\hline & Promotion Mix & $-0,007$ & 0,052 & $-0,014$ & $-0,138$ & 0,891 \\
\hline
\end{tabular}


Pada Tabel 12. dapat dilhat bahwa nilai signifikansi dari variabel promotion mix sebesar 0,891. Nilai tersebut lebih besar dari 0,05 yang berarti tidak terdapat pengaruh antara variabel bebas terhadap absolute residual. Sehingga model yang dibuat tidak mengandung heteroskedastistas.

Tabel 13.

Hasil Uji Heteroskedastistas Struktur 2

\begin{tabular}{|c|c|c|c|c|c|}
\hline \multirow{2}{*}{ Model } & \multicolumn{2}{|c|}{$\begin{array}{c}\text { Unstandardized } \\
\text { Coefficients }\end{array}$} & \multirow{2}{*}{$\begin{array}{c}\begin{array}{c}\text { Standardized } \\
\text { Coefficients }\end{array} \\
\text { Beta }\end{array}$} & \multirow{2}{*}{$\mathbf{t}$} & \multirow{2}{*}{ Sig. } \\
\hline & B & $\begin{array}{c}\text { Std. } \\
\text { Error }\end{array}$ & & & \\
\hline 2 (Constant) & 0,626 & 0,145 & \multirow{3}{*}{$\begin{array}{l}-0,101 \\
-0,190\end{array}$} & 4,317 & 0,000 \\
\hline Promotion mix & $-0,042$ & 0,046 & & $-0,899$ & 0,371 \\
\hline Brand equity & $-0,078$ & 0,046 & & $-1,701$ & 0,092 \\
\hline
\end{tabular}

Sumber: Data diolah, 2018

Pada Tabel 13. dapat dilhat bahwa nilai signifikansi dari variabel promotion mix sebesar 0,371, dan variabel brand equity sebesar 0,092. Nilai tersebut lebih besar dari 0,05 yang berarti tidak terdapat pengaruh antara variabel independen terhadap absolute residual. Sehingga model yang dibuat tidak mengandung heteroskedastistas.

Tabel 14.

Hasil Analisis Jalur Persamaan Regresi 1

\begin{tabular}{cccccc}
\hline \multirow{2}{*}{ Model } & \multicolumn{2}{c}{ Unstandardized Coefficients } & $\begin{array}{c}\text { Standardized } \\
\text { Coefficients }\end{array}$ & t & Sig. \\
\cline { 2 - 5 } & B & Std. Error & Beta & & \\
\hline $1 \quad$ (Constant) & 1,653 & 0,274 & & 6,032 & 0,000 \\
Promotion Mix & 0,481 & 0,089 & 0,480 & 5,420 & 0,000
\end{tabular}

$\mathrm{R}^{2}: 0,231 \quad$ F Statistik $: 29,372 \quad$ Sig F $: 0,000$

Sumber: Data diolah, 2018

Berdasarkan hasil analisis jalur substruktur 1 seperti yang disajikan pada Tabel 14, maka persamaan strukturnya adalah sebagai berikut:

$$
\begin{aligned}
& \mathrm{M}=\beta_{1} \mathrm{X}+\mathrm{e}_{1} \ldots \ldots \\
& \mathrm{M}=0,480 \mathrm{X}+\mathrm{e}_{1}
\end{aligned}
$$

Berdasarkan hasil analisis pengaruh promotion mix terhadap brand equity diperoleh nilai Sig. $\mathrm{t}$ sebesar 0,000 dengan nilai koefisien beta 0,480. Nilai Sig. $\mathrm{t}$ $0,000<0,05$ mengindikasikan bahwa $\mathrm{H}_{0}$ ditolak dan $\mathrm{H}_{1}$ diterima. Hasil ini mempunyai arti bahwa promotion mixberpengaruh positif dan signifikan terhadap brand equity.

Berdasarkan hasil analisis jalur substruktur 2 seperti yang disajikan pada Tabel 15, maka persamaan strukturalnya adalah sebagai berikut:

$$
\begin{aligned}
& \mathrm{Y}=\beta_{2} \mathrm{X}+\beta_{3} \mathrm{M}+\mathrm{e}_{2} \ldots \ldots \ldots \ldots \ldots \ldots \\
& \mathrm{Y}=0,563 \mathrm{X}+0,354 \mathrm{M}+\varepsilon_{2} .
\end{aligned}
$$


Tabel 15.

Hasil Analisis Jalur Persamaan Regresi 2

\begin{tabular}{|c|c|c|c|c|c|}
\hline \multirow{2}{*}{ Model } & \multicolumn{2}{|c|}{$\begin{array}{c}\text { Unstandardized } \\
\text { Coefficients }\end{array}$} & \multirow{2}{*}{$\begin{array}{c}\begin{array}{c}\text { Standardized } \\
\text { Coefficients }\end{array} \\
\text { Beta }\end{array}$} & \multirow{2}{*}{$\mathbf{t}$} & \multirow{2}{*}{ Sig. } \\
\hline & B & $\begin{array}{c}\text { Std. } \\
\text { Error }\end{array}$ & & & \\
\hline 1 (Constant) & 0,056 & 0,232 & \multirow{3}{*}{$\begin{array}{l}0,563 \\
0,354\end{array}$} & 0,239 & 0,812 \\
\hline Promotion mix & 0,589 & 0,073 & & 8,041 & 0,000 \\
\hline Brand equity & 0,370 & 0,073 & & 5,062 & 0,000 \\
\hline $\mathrm{R} 2^{2}: 0,634$ & F Statistik : 84,072 & \multicolumn{2}{|c|}{ Sig. F : 0,000} & & \\
\hline
\end{tabular}

Sumber: Data diolah, 2018

Berdasarkan hasil analisis pengaruh promotion mix terhadap customer loyalty, diperoleh nilai Sig. $\mathrm{t}$ sebesar 0,000 dengan nilai koefisien beta 0,563. Nilai Sig. t 0,000 $<0,05$ mengindikasikan bahwa $\mathrm{H}_{0}$ ditolak dan $\mathrm{H}_{1}$ diterima. Hasil ini mempunyai arti bahwa promotion mixberpengaruh positif dan signifikan terhadapcustomer loyalty. Berdasarkan hasil analisis pengaruh brand equity terhadap customer loyaltydiperoleh nilai Sig. $\mathrm{t}$ sebesar 0,000 dengan nilai koefisien beta 0,354 . Nilai Sig. $\mathrm{t} 0,000<0,05$ mengindikasikan bahwa $\mathrm{H}_{0}$ ditolak dan $\mathrm{H}_{1}$ diterima. Hasil ini mempunyai arti bahwa brand equity berpengaruh positif dan signifikan terhadapcustomer loyalty. Hasil dari pengujian variabel mediasi didapatkan $Z$ hitung sebesar 3,6226 > 1,96 dengan tingkat signifikan sebesar $0,000<0.05$ yang berarti $\mathrm{H}_{0}$ ditolak dan $\mathrm{H}_{1}$ diterima yang berarti variabel brand equity memediasi variabel promotion mix terhadap customer loyalty pada pengguna laptop merek Acer di kota Denpasar

Berdasarkan hasil analisis promotion mix berpengaruh positif dan signifikan terhadap brand equity yang menunjukkan bahwa, semakin baik promosi pada suatu produk maka tingkat ingatan konsumen mengenai merek atau brand akan semakin tinggi, dan sebaliknya jika promosi laptop Acer menurun, maka tingkat ingatan konsumen mengenai merek atau brand menurun.

Hasil rangkuman penilai responden yang disajikan dalam deskripsi variabel penelitian menunjukkan bahwa penilaian responden terhadap promotion mix berada dalam kategori tinggi sehingga tingkat promotion mix terhadap laptop Acer mendapat penilaian baik. Indikator pemasaran langsung memiliki nilai penilaian deskriptif tertinggi pada variabel promotion mix, yang artinya sebagian besar responden merasa pemasaran langsung yang dilakukan Acer sudah baik. Semakin baiknya pemasaran langsung yang dilakukan perusahaan Acer, maka tingkat ingatan merek atau brand equity Acer di pikiran konsumen akan semakin tinggi. Hal ini didukung dengan hasil pada penyajian deskripsi variabel penelitian brand equity yang memperoleh kategori tinggi.

Berdasarkan hasil analisis promotion mix berpengaruh positif dan signifikan terhadap customer loyalty yang menunjukan bahwa, semakin baik promosi dari suatu produk maka tingkat kesetiaan atau loyalitas pelanggan terhadap suatu produk akan semakin tinggi, dan sebaliknya jika promosi laptop Acer menurun, maka potensi terjadinya customer loyalty akan menurun.

Hasil rangkuman penilai responden yang disajikan dalam deskripsi variabel penelitian menunjukkan bahwa penilaian responden terhadap customer loyalty 
berada dalam kategori tinggi. Hal ini berarti secara keseluruhan responden mempresentasikan bahwa sebagian besar responden loyal terhadap laptop Acer karena mereka mengetahui promosi yang dilakukan laptop Acer. Indikator kemudahan memiliki nilai penilaian deskriptif tertinggi pada variabel customer loyalty, yang artinya sebagian besar responden merasa laptop Acer mudah digunakan sehingga responden suka menggunakannya. Sedangkan penilaian responden terhadap promotion mix, indikator pemasaran langsung yang mendapatkan nilai tertinggi. yang artinya jika semakin baiknya pemasaran langsung yang dilakukan perusahaan Acer, maka palnggan akan suka menggunakan laptop Acer dan tingkat loyalitas pelanggan pada Acer akan semakin tinggi.

Berdasarkan hasil analisis brand equity berpengaruh positif dan signifikan terhadap customer loyalty yang menunjukkan bahwa, semakin tinggi tingkat ingatan konsumen mengenai merek atau brand maka kesetiaan atau loyalitas pelanggan terhadap suatu produk akan semakin tinggi. dan sebaliknya jika brand equity laptop Acer menurun, maka potensi terjadinya customer loyalty akan menurun.

Hasil rangkuman penilai responden yang disajikan dalam deskripsi variabel penelitian menunjukkan bahwa penilaian responden terhadap brand equity berada dalam kategori tinggi sehingga tingkat brand equityterhadap laptop Acer mendapat penilaian baik.Indikator loyalitas merek memiliki nilai penilaian deskriptif tertinggi pada variabel brand equity, yang artinya sebagian besar responden merasa sebagian besar responden loyal dengan merek Acer karena Acer memiliki gambaran merek laptop yang bisa dimiliki oleh semua golongan. Maka jika semakin loyalnya konsumen pada merek Acer, maka tingkat loyalitas pelanggan pada Acer akan semakin tinggi. Hal ini didukung dengan hasil pada penyajian deskripsi variabel penelitian customer loyalty yang memperoleh kategori tinggi.

Pengaruh promotion mix terhadap customer loyalty yang dimediasi oleh brand equity pada pengguna laptop merek Acer telah diuji dalam penelitian ini. Nilai VAF yaitu 0,232 yang menunjukkan bahwa brand equity memediasi pengaruh promotion mix terhadap customer loyalty secara parsial. Uji Sobel yang telah dihitung memperkuat hasil tersebut dengan nilai koefisien $\mathrm{z}$ yang diperoleh adalah 3,622 >1,96 dengan tingkat signifikansi $0,000<0,05$. Sehingga dapat dikatakan bahwa brand equity memediasi pengaruh promotion mix terhadap customer loyalty. Hal ini sesuai dengan penelitian yang dilakukan oleh $\mathrm{Hu}$ (2012) dengan hasil ekuitas merek memediasi hubungan antara bauran promosi, kualitas layanan dan loyalitas pelanggan. Ini berarti ekuitas merek memainkan peran penting untuk mempengaruhi persepsi pelanggan pada promosi, kualitas layanan dan loyalitas pelanggan.

Dapat dikatakan bahwa, semakin baiknya promosi-promosi yang dilakukan oleh Acer maka didalam pikiran konsumen akan semakin ingat pada merek Acer, hal tersebut nantinya mempengaruhi seseorang untuk tidak berpindah pada merek lain dan akan tetap setia serta loyal pada produk laptop merek Acer, begitu pula sebaliknya. Maka hasil penelitian ini adalah promotion mix berpengaruh terhadap 
customer loyalty melalui brand equity sebagai variabel mediasi pada pengguna laptop merek Acer.

\section{SIMPULAN}

Berdasarkan hasil pembahasan penelitian yang telah dilakukan, maka kesimpulan yang didapatkan ialah promotion mix berpengaruh positif dan signifikan terhadap brand equity pada laptop merek Acer. Dapat dikatakan bahwa, semakin baik promosi pada suatu produk maka tingkat ingatan konsumen mengenai merek atau brand akan semakin tinggi.cPromotion mix berpengaruh positif dan signifikan terhadap customer loyalty pada laptop merek Acer. Hasil menunjukkan bahwa, semakin baik promosi dari suatu produk maka tingkat kesetiaan atau loyalitas pelanggan terhadap suatu produk akan semakin tinggi. Brand equity berpengaruh positif signifikan terhadap customer loyalty pada laptop merek Acer. Hasil menunjukkan bahwa, semakin tinggi tingkat ingatan konsumen mengenai merek atau brand maka kesetiaan atau loyalitas pelanggan terhadap suatu produk akan semakin tinggi. Brand equity memediasi pengaruh promotion mix terhadap customer loyalty pada laptop merek Acer. Ini berarti brand equity memainkan peran penting untuk mempengaruhi persepsi pelanggan pada promotion mix dan customer loyalty. Promosi yang dilakukan oleh Acer akan berpengaruh pada ingatan konsumen terhadap merek Acer sehingga konsumen memilih untuk tetap loyal dengan membeli dan menggunakan laptop Acer atau memilih untuk mengganti produk mereka dengan produk yang dapat memenuhi kebutuhan dan keinginannya.

Berdasarkan kesimpulan yang telah didapat, maka saran yang dapat diberikan adalah sebagai berikut, untuk lebih memperhatikan promosi penjualan dan penjualan perorangan pada promotion mix, karena dalam deskripsi penilaian konsumen terhadap promotion mixkonsumen memberikan penilaian yang paling rendah terhadap kedua indikator tersebut. Meningkatkan promosi penjualan dengan cara memberikan potongan harga, presentasi hadiah berulang seperti geratis aksesoris laptop pada tipe tertentu, menyebarkan catalog promosi, dan sebagainya. Meningkatkan penjualan perorangan dengan cara berkonsentrasi pada pelatihan tenaga penjualan di berbagai bidang seperti komunikasi sosial, menjadi sales yang handal agar konsumen tertarik untuk membeli produk laptop Acer.

\section{REFERENSI}

Abdurrahman, N. H. (n.d.). Manajemen Pemasaran (Cetakan Pe). Bandung: Pustaka Setia.

Acer Inc Wikipedia Indonesia. (2017). Retrieved December 22, 2017, from https://id.wikipedia.org/wiki/Acer_Inc

Acer Indonesia. (2018). Retrieved March 24, 2018, from https://www.acerid.com

Alghofari, A. K., Pratiwi, I., \& Astuti, P. Y. (2009). Analisis Pengaruh Brand Equity Terhadap Pembentukan Customer Loyalty pada Jenis Merek Pasta Gigi Dengan Analisis SEM: Studi pada Mahasiswa UMS. Simposium Nasional RAPI VIII, 4(4), 58-65.

Alyasa, F. H., \& Kuntilawati, N. (2012). Analisis Pengaruh Ekuitas Merek (Brand 
Equity) Terhadap Loyalitas Konsumen pada Produk Sepeda Motor Kawasaki Ninja: Studi pada Mahasiswa Universitas Malang. Jurnal Mahasiswa Q-Man, 1(3), 1-14.

Anindhyta, B., Surachman, Djumilah, H., \& Djumahir. (2013). Brand Equity and Customer Satisfaction as the Mediation of Advertisement Influence and the Service Quality to Loyalty the Passengers of International Flight at Garuda Indonesia Airlines. IOSR Journal of Business and Management, 9(2), 1-15. https://doi.org/10.9790/487X-0920115

Brunello, A. (2013). The Relationship Between Integrated Marketing Communication and Brand Equity. International Journal of Communication Research, 3(10), 9-14.

Chang, H. H., \& Wang, H. (2011). The Moderating Effect Of Customer Perceived Value On Online Shopping Behaviour. Online Information Review, 35(3), 333-359. https://doi.org/10.1108/14684521111151414

Charanah, J., \& Njuguna, R. K. (2015). The Effects of Promotional Mix Tools on Brand Equity Among Hospitals in Nairobi County. International Journal of Sales, Retailing and Marketing, 4(6), 45-51.

Chriswardana, D. B. (2015). Pengaruh Country of Origin Produk Televisi LG Terhadap Niat Beli Konsumen Dengan Ekuitas Merek Sebagai Variabel Pemediasi. Jurnal Bianglala Informatika, 3(1), 74-82.

Danibrata, A. (2011). Pengaruh Integrated Marketing Communication Terhadap Brand Equity Pada Sebuah Bank Pemerintah di Jakarta. Jurnal Bisnis Dan Akuntansi, 13(1), 21-38.

Darmawangsa, A. A. B., \& Ardani, I. G. A. K. S. (2015). Pengaruh Komunikasi Pemasaran Terpadu dan Ekuitas Merek Terhadap Loyalitas Konsumen. EJurnal Manajemen Unud, 4(8), 2163-2175.

Dewantara, A. A., \& Nurcahya, I. K. (2017). Peran Ekuitas Merek dalam Memediasi Bauran Promosi dengan Keputusan Pembelian. E-Jurnal Manajemen Unud, 6(8), 4538-4568.

Diansyah, \& Putera, R. M. (2017). Pengaruh Ekuitas Merek dan Promosi Penjualan Terhadap Loyalitas Pelanggan Dimediasi Keputusan Pembelian. Media Ekonomi Dan Manajemen, 32(2), 97-109.

Faries, H. E., \& Budiyanto. (2017). Pengaruh Kualitas Pelayanan dan Promosi Terhadap Loyalitas Konsumen Studi pada Dealer Motor Honda di Surabaya. Jurnal Ilmu Dan Riset Manajemen, 6(2), 22-45.

Ghaisani, R. P., Darsiharjo, \& Miftah, R. (2016). Pengaruh Promosi Terhadap Loyalitas Konsumen di Suis Butchr Stak House Setiabudhi Bandung. EJournal UPI, 3(1), 255-264.

Ghozali, I. (2013). Aplikasi Analisis Multivariate dengan Program SPSS (Edisi Ketu). Semarang: Badan Penerbit Universitas Diponegoro.

Hosseini, M. H., \& Moezzi, H. (2015). Exploring Impact of Marketing Mix on 
Brand Equity in Insurance Industry (Case Study: Asia Insurance Firm, Iran). Journal of Asian Scientific Research, 5(1), 38-45. https://doi.org/10.18488/journal.2/2015.5.1/2.1.38.45

Hu, Y. J. (2011). How Brand Equity, Marketing Mix Strategy and Service Qualityaffect Customer Loyalty: The Case of Retail Chain Stores in Taiwan. The International Journal of Organizational Innovation, 4(1), 59-73.

Hu, Y. J. (2012). The Moderating Effect of Brand Equity and The Mediating Effect of Marketing Mix Strategy on The RelationshipBetween Service Quality and Customer Loyalty: The Case of Retail Chain Stores in Taiwan. The International Journal of Organizational Innovation, 5(1), 155-162.

Istijanto. (2005). Aplikasi Praktis Riset Pemasaran, Plus 36 Topik Riset Pemasaran Siap Terap. Jakarta: Gramedia Pustaka Utama.

Khanfar, I. A. (2016). The Effect of Promotional Mix Element on Consumer Buying Decision of Mobile Service: The Case of Umniah Telecomminucation Company at Zarqa City- Jordan. European Journal of Business and Management, 8(5), 94-100.

Kotler, P., \& Keller, K. L. (2009). Manajemen Pemasaran (Edisi Tiga). Jakarta: Erlangga.

Kumar, S., \& Patra, S. (2017). Does Promotion Mix Really Help to Enhance Brand Equity: A Literature Review. Indian Journal of Commerce \& Management Studies, 8(2), 80-86. https://doi.org/10.18843/ijcms/v8i2/11

Maharani, D. P. (2010). Ekuitas Merek Terhadap Loyalitas Studi Korelasi Pengaruh Ekuitas Merek Terhadap Pembentukan Loyalitas Konsumen dalam Pemilihan Jenis Provider IM3 dan XL di Kalangan Mahasiswa Swadana Transfer S1 Komunikasi Angkatan 2008. Skripsi Sarjana Fakultas Ilmu Sosial Dan Ilmu Politik Universitas Sebelas Maret, Surakarta.

Norouzi, A., \& Hosienabadi, B. F. (2011). The Effects of Brand's Country-ofOrigin Image on The Formation of Brand Equity. Australian Journal of Basic and Applied Sciences, 5(12), 766-770.

Nuraini. (2009). Analisis Pengaruh Kualitas Produk, Kualitas Pelayanan, Desain Produk, Harga dan Kepercayaan Terhadap Loyalitas Pelanggan. Skripsi Sarjana Fakultas Ekonomi Universitas Diponegoro.

Permatasari, D. N. (2014). Analisis Pengaruh Kualitas Produk dan Bauran Promosi Terhadap Loyalitas Konsumen Smartphone Blackberry Studi pada Mahasiswa di Beberapa Universitas di Jakarta. Journal MIX, 6(1), 57-69.

Peter, J. P., \& Olson, J. C. (1999). Consumer Behavior. Jakarta: Erlangga.

Pourdehghan, A. (2015). The Impact of Marketing Mix Elements on Brand Loyalty: A Case Study of Mobile Phone Industry. Marketing and Branding Research, 2(15), 44-63. https://doi.org/10.19237/MBR.2015.01.04

Rohollah, A., Mehrani, H., \& Didekhani, H. (2014). A Study on The Effect of Selected Marketing Mix Element on Brand Equity with Mediating Role of 
Brand Equity in Etika Chain Stores-Golestan Province. Kuwait Chapter of Arabian Journal of Business and Management Review, 3(1), 603-621.

Sembeng, L. L. (2016). Pengaruh Promosional Mix Terhadap Loyalitas Pelanggan Kartu Halo Pada Pt. Telkomsel Grapari Manado. Jurnal EMBA, 2(1), 1122.

Shafi, S., \& Madhavaiah, C. (2013). An Empirical Study on The Impact of Promotional Mix Elements on Brand Equity: A Study of FMCG in India. Madras University Journal OfBusiness And Finance, 1(2), 46-56.

Shahroudi, K., \& Naimi, S. S. (2015). The Impact of Brand Image on Customer Satisfaction and Loyalty Intention (Case Study: Consumer of Hygiene Products). International Journal of Engineering Innovation \& Research, 3(1), 57-.

Sugiyono. (2014). Metode Penelitian Kuantitatif Kualitatif dan R\&D. Bandung: Alfabeta.

Sukmarini, A. V., Cangara, H., \& Amar, M. Y. (2013). Strategi Promosi Mempertahankan Loyalitas Pelanggan Mobil Merek Toyota PT. H. Kalla dalam Persaingan Otomotif di Makassar. Jurnal Komunikasi Kareba, 2(4), 369-378.

Sumarwan, U., Djunaidi, A., Aviliani, S., Sayono, J. A., \& Budidarmo, R. R. (2009). Pemasaran Strategik; Strategi untuk Pertumbuhan Perusahaan dalam Penciptaan Nilai bagi Pemegang Saham (Edisi Satu). Jakarta: Inti Prima Promosindo.

Supranto, \& Limakrisna, N. (2011). Perilaku Konsumen dan Strategi Pemasaran (Edisi Kedu). Jakarta: Mitra Wacana Media.

TOP Brand Award. (2018). Retrieved March 24, 2018, from http://www.topbrand-award.com

Utama, M. S. (2016). Aplikasi Analisa Kuantitatif. Denpasar: Sastra Utama.

Velnampy, T., \& Sivanandamoorthy, S. (2012). Customer Relationship Marketing and Customer Satisfaction: A Study on Mobile Service Providing Companies in Sri Lanka. Global Journal of Management and Business Research, 12(1), 1-7.

Williams, B. K., \& Sawyer, S. C. (2011). Pengenalan Praktis Dunia Komputer dan Komunika. Yogyakarta: Penerbit Andi.

Yeni, N. (2016). Pengaruh Bauran Pemasaran Terhadap Loyalitas Pelanggan pada Butik Zoya Busana Muslim di Samarinda. E-Journal Ilmu Administrasi Bisnis, 4(1), 63-75. 